holt, Mulder and Lambert, 1964). In the few previously reported cases with papilloedema there was a higher incidence of cranial nerve palsies (Morley and Reynolds, 1966). We confirm this association and it seems probable that papilloedema was due to actual involvement of the optic nerve-optic neuritis. Other authors have disputed this because visual impairment is extremely uncommon but in this patient some reduction of visual acuity occurred. Other possible causes of papilloedema are impairment of absorption of cerebrospinal fluid due to protein occlusion of the arachnoid villi or raised intracranial pressure, but in this case neither seems likely as the protein level was not grossly elevated and cerebrospinal fluid pressure was normal. Respiratory inadequacy has not usually been associated with papilloedema in previous cases (Morley and Reynolds, 1966) and it is of interest that ophthalmic changes developed here at the time when respiratory function was improving.

Urethritis preceded the onset of neurological symptoms. One culture failed to grow gonococci but the presence of Gram-negative diplococci and many pus cells in the urethral discharge and the immediate response to penicillin are strongly suggestive of gonorrhoea rather than any other form of urethritis. It may be that this is another example of an infective stimulus triggering an auto-immune mechanism. This is supported by the time sequence, with neuro- logical symptoms following 3 weeks after the pre- $\frac{2}{\infty}$ cipitating illness and by the finding of anti-nuclear 0 factor in the blood throughout the illness.

\section{Acknowledgments}

We wish to thank Dr A. J. Daly, Consultant Physician, for allowing us to publish details of his patient and Dr G. D. Morrison, Consultant Venereologist, for his help and advice.

\section{References}

Clarke, E., Bayliss, R.I.S. \& CoOper, R. (1954) Landry-Guillain-Barré syndrome: cardiovascular complications, $\vec{\omega}$ treatment with A.C.T.H. and cortisone. British Medical $\mathscr{W}$ Journal, 2, 1504.

Guillain, Georges, Barré, J.A. \& Strohl, A. (1916) Sur un syndrome de radiculo-névrite avec hyperalbuminose du liquide céphalo-rachidien sans réaction cellulaire. $\mathrm{Re}-\mathrm{G}$ marques sur les caractères cliniques et graphiques des $\overrightarrow{i r}$ reflexes tendineux. Bulletin de la Société de Médecine de l'Hopital de Paris, 40, 1462.

HAYMAKER, W. \& KERNOHAN, J.W. (1949) The Landry- क Guillain-Barré syndrome. A clinico pathologic report of fifty fatal cases and a critique of the literature. Medicine $\mathrm{O}$ (Baltimore), 28, 59.

MoRley, J.B. \& ReYNolds, E.H. (1966) Papilloedema and $\vec{\omega}$ the Landry-Guillain-Barré syndrome. Brain, 89, 205.

SABIN, A.B. \& ARING, C.D. (1941) Visceral lesions in infectious polyneuritis. American Journal of Pathology, 17, 469.

WiederholT, W.C., MULDER, D.W. \& LAMBERT, E.H. (1964) The Landry-Guillain-Barré-Strohl syndrome or polg radiculoneuropathy: Historical review, report on ninet seven patients, and present concepts. Mayo Clinic Procee ings, 39, 427.

\title{
Spirillum endocarditis
}

\author{
C. S. McIntosh \\ M.B., M.R.C.P.
}

P. J. VICKERS

M.B., B.S., M.R.C.S., L.R.C.P.

\author{
A. J. ISAACS \\ M.A., B.M., M.R.C.P. \\ Westminster Hospital, and Endocrine Unit, New End Hospital, London
}

\section{Summary}

A case of Spirillum endocarditis causing severe aortic regurgitation in a 26-year-old man is reported. The infection responded to treatment with oxytetracycline followed by ampicillin, but the valvular damage led to progressive left ventricular failure. The valve was replaced with a fresh nutrient homograft and the patient made a good recovery. A normal aortic valve appeared to have been infected.

\section{Introduction}

Infections with organisms of the genus Spirillum are uncommon and can be fatal. Endocarditis due to such infection is rare and occurs in the presence of valvular heart damage or in association with a severe chronic debilitating condition such as aplastic anaemia. We report a case of Spirillum endocarditis in a previously healthy young man with normal heart valves. 


\section{Case report}

The patient, a 26-year-old Englishman, was admitted with a 4-day history of rigors, sweats, tiredness and vomiting. These symptoms began 14 days after his return from a 4-month stay in Morocco. He was a homosexual and had had non-specific urethritis 4 years previously, but no other relevant illnesses. He was a heavy drinker and smoked up to fifty cigarettes daily. There was no history of drug addiction.

On admission, he had a swinging pyrexia up to $40^{\circ} \mathrm{C}\left(104^{\circ} \mathrm{F}\right)$ with frequent rigors. There were no abnormal physical signs and in particular no cardiac murmurs or splenomegaly. He was infested with crab lice (Phthirus pubis). Investigations showed a sedimentation rate of $33 \mathrm{ml} /$ first hr (Westergren), a haemoglobin of $14.4 \mathrm{~g}$ and a normal white cell count and differential. No malarial parasites were seen. Tests of liver function were normal except for a transient increase in SGPT to 30 i.u. (normal, 4-21). The urine was normal microscopically and on culture.

Two days after his admission he developed aortic incompetence with loud aortic systolic and early diastolic murmurs, a collapsing pulse and a blood pressure of 150/60. A few days later the splenic tip became palpable. By this time, four separate blood cultures had grown a Gram-negative spiral organism, which on preliminary testing with antibiotics appeared to be sensitive to oxytetracycline, erythromycin and gentamicin.

Treatment was started with i.m. gentamicin $1 \mathrm{mg} /$ $\mathrm{kg}$ body weight every $8 \mathrm{hr}$ and oral erythromycin $500 \mathrm{mg} 6$-hourly. His pyrexia persisted, despite an increase in the dose of gentamicin and after a week the treatment was changed to oxytetracycline in an initial dose of $2 \mathrm{~g}$ daily by intravenous infusion followed by $500 \mathrm{mg}$ 6-hourly by mouth. At this time the patient was also given a course of metronidazole. Cysts of Giardia lamblia had been found in his stools and it was considered possible that the drug might also be active against the anaerobic Spirillum.

On this regime the patient's temperature settled quickly. His ESR fell to $14 \mathrm{~mm} / \mathrm{hr}$ and his other tests, including urinalysis, blood urea and serological investigations, were unchanged. There was no evidence of cardiac failure and his chest X-ray and ECG remained normal. After 5 weeks he was discharged still taking oral oxytetracycline and remained well until 10 days later when he returned with an embolic occlusion of his left brachial artery. This was treated with intravenous heparin and resolved satisfactorily. At this time his ESR rose to $42 \mathrm{~mm} /$ first $\mathrm{hr}$ and the ECG showed early left ventricular hypertrophy.

After a total of 7 weeks of oxytetracycline treatment he was given ampicillin in a dose of $500 \mathrm{mg}$ 6-hourly for 5 weeks. Antibiotic therapy was then stopped and there was no further evidence of active infection. Over the next few months, however, he developed increasing cardiomegaly and his ECG showed a left ventricular hypertrophy and strain pattern. The patient began to complain of increasing dyspnoea on exercise and required large doses of diuretics for relief. Eighteen weeks after the onset of his illness he was admitted to the National Heart Hospital for investigation and subsequent aortic valve replacement.

At operation a small fossa ovalis atrial septal defect $(4 \mathrm{~mm} \times 3 \mathrm{~mm})$ was found. The aortic valve itself appeared to have been a normal valve originally. The left coronary cusp was normal, but the right coronary cusp contained a $5 \mathrm{~mm}$ perforation with thickened and rolled edges (Fig. 1). The noncoronary cusp was almost totally destroyed. The small atrial septal defect was closed and the aortic valve was resected and replaced with a fresh nutrient homograft. The valve was tested and found competent.

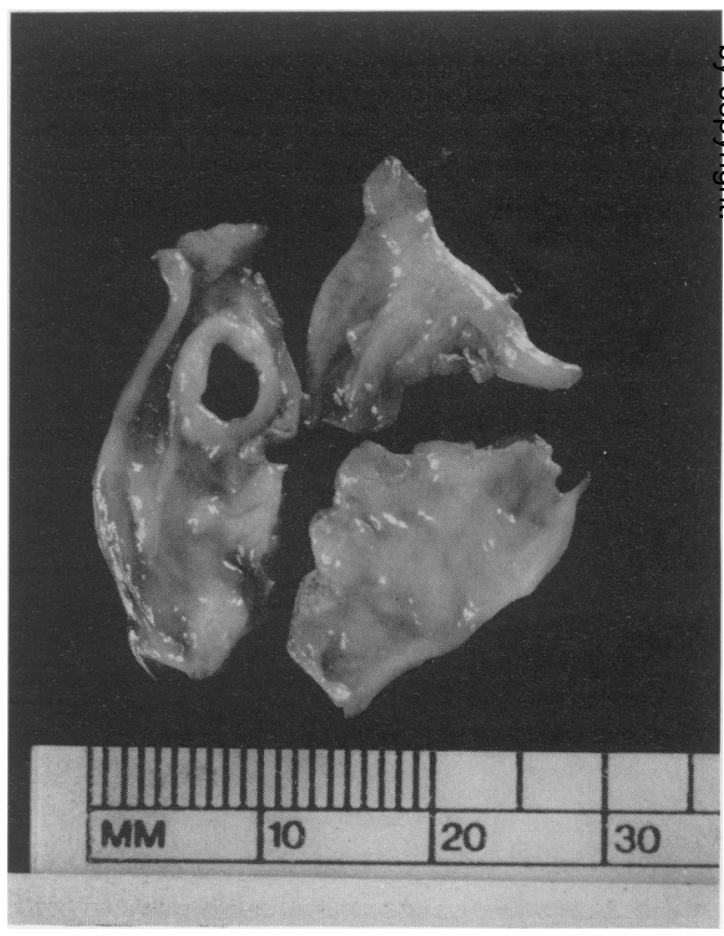

FIG. 1

The patient's post-operative course was uneventful. He made a good recovery and remains well at the time of writing. 


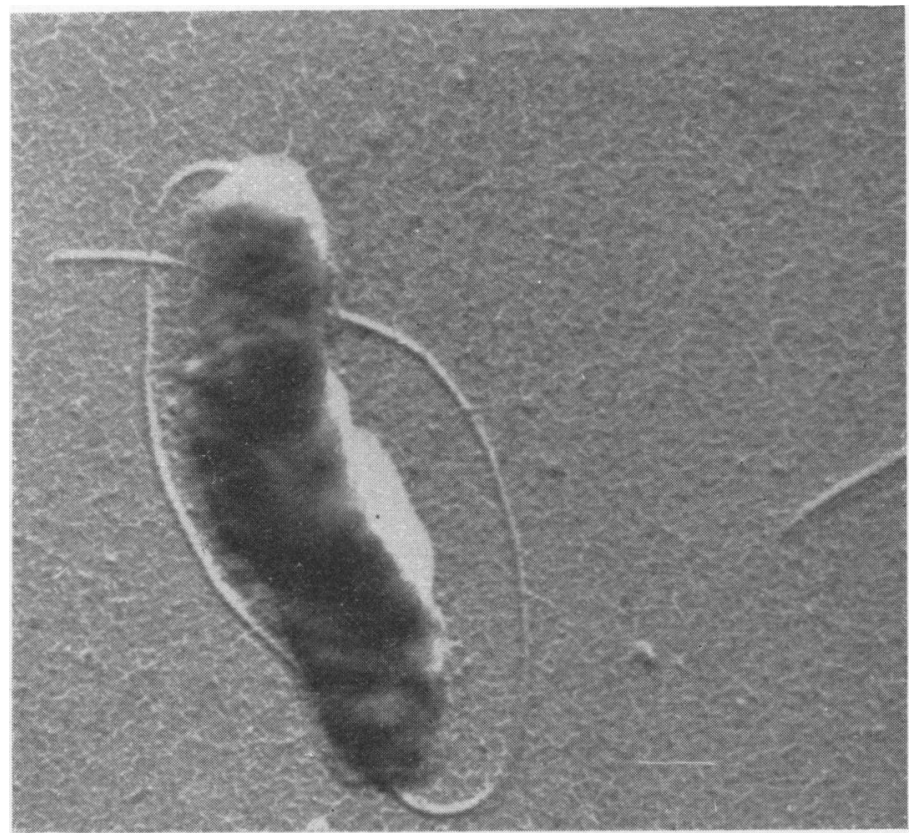

Fig. 2

TABLE 1

\begin{tabular}{lc}
\hline & MIC $(\mu \mathrm{g} / \mathrm{ml})$ \\
\hline Erythromycin & $2 \cdot 0$ \\
Oxytetracycline & $0 \cdot 5$ \\
Gentamicin & $1 \cdot 0$ \\
Streptomycin & $1 \cdot 0$ \\
Ampicillin & $4 \cdot 0$ \\
Cephaloridine & $0 \cdot 25$ \\
Chloramphenicol & 32.0 \\
Metronidazole & 8.0 \\
\hline
\end{tabular}

\section{Bacteriology}

A pure growth of spiral Gram-negative bacilli (Fig. 2) was isolated from four successive anaerobic $0.3 \%$ glucose broth cultures containing thioglycollate. The aerobic cultures remained sterile. The organisms were actively motile possessing single bipolar flagella. Average dimensions were $4.0 \mu \times$ $0.4 \mu$ with a width of spiral of $1.3 \mu$ and a wavelength of $2.0 \mu$. In older cultures larger forms of up to six wavelengths appeared. The spirilla grew slowly on $5 \%$ blood agar incubated in hydrogen with $10 \%$ $\mathrm{CO}_{2}$, forming smooth grey pin-point colonies after $48 \mathrm{hr}$ at $36^{\circ} \mathrm{C}$. Oxidase and catalase reactions were positive but the organism did not produce indole and failed to ferment carbohydrates or liquify gelatin. Minimum inhibitory concentrations (MIC's) of various antibiotics were determined using $5 \%$ blood agar medium incorporating the antibiotic, incubated anaerobically and read after $48 \mathrm{hr}$.
The organism remained viable and with a stable $\overrightarrow{0}$ antibiotic sensitivity pattern after freeze drying.

The valve cusps removed at operation were both examined histologically and cultured for microorganisms, but none was seen.

\section{Discussion}

Spirillum spp. are widely distributed in nature, being found particularly in fresh or salt water rich in organic matter, and as parasites of shellfish (Hylemon et al., 1973). S. minus, the causative organism of spirillary rat-bite fever (sodoku), is the only member of the genus well recognized as a pathogen of man and small mammals (Breed, Murray and Smith, 1969). Early reports (Futaki et al., 1916, 1917; Joekes, 1925; Foncannon, 1930) of successful culture of this organism in vitro have not, however, been confirmed. Other apparently pathogenic spirilla have been isolated from the blood on rare occasions (Lamb and Paton, 1913; Soper, 1913; Hitzig and Liebesman, 1944; Shwartzman et al., 1951; Edwards and Kraus, 1960; Kowal, 1961; Finland and Barnes, 1970; Webster, 1973) although their precise identification remains uncertain.

To our knowledge, only four previous cases of Spirillum endocarditis have been recorded in the English literature. Of these cases, three were known to have valvular disease of the heart and one had $\stackrel{0}{+}$ chronic aplastic anaemia. Apart from an episode of non-specific urethritis 4 years previously, our patient 
was in good health and had no evidence of valvular disease or reduced immunity. It is unlikely that the small secundum atrial septal defect predisposed to infection of the aortic valve. Classical sodoku is transmitted by the bites of rats and small mammals, but this history is not usually obtained in other Spirillum infections (Kowal, 1961) and was not obtained in our patient. In view of his promiscuous homosexual behaviour it is possible that the infection was transmitted by venereal contact, but since the reservoir of the organism is unknown this must remain speculative.

Rat-bite fever normally responds to penicillin but the organism isolated from our patient was resistant to this drug in vitro, and treatment depended mainly on oxytetracycline. The MIC of metronidazole is sufficiently high for it to be unlikely to have affected the outcome in the dosage employed, though its use in the treatment of other anaerobic and fusospiochaetal infections is well recognized.

\section{Acknowledgments}

We wish to thank Dr R. I. S. Bayliss for permission to report this case as well as Mr D. J. Parker and Dr A. G. Leatham for supplying details of their findings.

\section{References}

Breed, R.S., Murray, E.G.D. \& SMith, N.R. (1969) In: Bergey's Manual of Determinative Bacteriology, 7th edn. Williams and Wilkins, Baltimore.

EdWARDS, C.E. \& KRAUS, R. (1960) Spirillum serpens meningitis: report of a case. New England Journal of $\frac{\widehat{Q}}{\mathrm{Q}}$ Medicine, 262, 458.

Finland, M. \& BARNes, M.W. (1970) Changing etiology of $\subseteq$ bacterial endocarditis in the antibacterial era. Annals of Internal Medicine, 72, 341.

FonCannon, F. (1930) Rat-bite fever. Journal of the Kansas Medical Society, 31, 331.

Futaki, K., Takaki, F., Taniguchi, T. \& Osumi, S. (1916) The cause of rat-bite fever. Journal of Experimental Medicine, 23, 249.

Futaki, K., TAKaki, F., TANiguchi, T. \& Osumi, S. (1917) Spirochaeta morsus muris, n.sp., the cause of rat-bite fever. Journal of Experimental Medicine, 25, 33.

Hitzig, W.M. \& Liebesman, A. (1944) Subacute endocarditis associated with infection with a Spirillum. Archives of Internal Medicine, 73, 415.

Hylemon, P.B., Wells J.S., JR, Kreig, N.R. \& JonNasch, H.W. (1973). The genus Spirillum; a taxonomic study. International Journal of Systemic Bacteriology, 23, 340.

Joekes, T. (1925) Cultivation of Spirillum of rat-bite fever Lancet, ii, 1225.

Kowal, J. (1961) Spirillum fever, report of a case and review of the literature. New England Journal of Medicine, 264, 123.

LAmb, A.R. \& Paton, F.W. (1913) A case of vegetative endocarditis caused by a hitherto undescribed Spirillum. Archives of Internal Medicine, 12, 259.

Shwartzman, G., Florman, A.L., Bass, M.H., Karelitz, S. \& RichtberG, D. (1951) Repeated recovery of a Spirillum by blood culture from two children with prolonged and recurrent fevers. Pediatrics, 8, 227.

SOPER, W.B. (1913) A case of Spirillum infection. Archives of Internal Medicine, 12, 273.

Webster, A.D.B. for AsHerson, G.L. (1973) Spirillun hepatitis in "acquired" hypogammaglobulinaemia with thyroiditis, pernicious anaemia and possible dermatitis̄ herpetiformis. Proceedings of the Royal Society of Medicine 66, 1126.

\title{
Hypertrophic osteoarthropathy associated with Fallot's tetralogy- a case report
}

\author{
B. Olu. George \\ M.R.C.P., L.M., L.R.C.S., L.R.C.P. \\ J. Olu. Mabayoje \\ F.R.C.P., F.M.C.P.

\section{Department of Medicine, Lagos University Teaching Hospital, Private Mail Bag 12003, Lagos, Nigeria}

\begin{abstract}
Summary
A case of Fallot's tetralogy associated with hypertrophic osteoarthropathy in a young Nigerian female is described. The clinical spectrum of hypertrophic osteoarthropathy is reviewed. The rarity of this syndrome is stressed. Some other aspects of the clinical manifestation of cyanotic congenital heart disease which may mimic the skeletal syndrome are mentioned.
\end{abstract}

\section{Introduction}

Hypertrophic osteoarthropathy is a rare syndrome characterized by clubbing of the fingers and toes, chronic periostitis, with periosteal new bone formation involving especially the distal ends of the long bones, joint pain and swelling, signs of autonomic disorder (flushing and blanching, and profuse sweating), and gynaecomastia. It has been described in association with many varied conditions, of which 